\title{
ACCEPTANCE ANALYSIS OF THE E-PROCUREMENT OF EAST JAVA PROVINCE USING TAM METHOD
}

\author{
Mas Odi ${ }^{1}$ | Erma Suryani*2
}

\footnotetext{
${ }^{1}$ Dept. of Management of Technology, Institut Teknologi Sepuluh Nopember, Surabaya, Indonesia

${ }^{2}$ Dept of Information System, Institut Teknologi Sepuluh Nopember, Surabaya, Indonesia
}

\section{Correspondence}

*Erma Suryani, Dept of Information System, Institut Teknologi Sepuluh Nopember, Surabaya, Indonesia. Email:

dsiahaan@its.ac.id

\section{Present Address}

Gedung Sistem Informasi, Kampus ITS Sukolilo, Surabaya 60111, Indonesia

\begin{abstract}
Technological developments have changed the system of the government. The East Java Provincial Government utilizes Information and Communication Technology for the procurement of goods and services. This study aims to measure the level of acceptance of technology in the system and the satisfaction of applications for the goods and services procurement in East Java Province. The results of this study can be used to improve the system that has been made. This study uses the Technology Acceptance Model (TAM) method in measuring using (5) aspects, namely Perception of Ease of Use, Benefits of Use, Attitudes toward behavior, Interest in Behavior, and Behavior. This study used 90 respondents. The results showed that from the regression test on the variable Perception of Ease of Use with Benefits of Use of 13.5\%, Perception of Ease of Use with Attitudes Against Behavior amounted to 38.7\%. Benefits of Using Attitudes Against Behavior was 23.9\%, Benefits of Use with Interest Behavior amounted to $11.5 \%$, Attitudes toward Behavior were Large with Interest in Behavior at $22.2 \%$. Benefits of Use with Behavior amounted to $10.1 \%$, and Interests in Behavior with Behavior were 13.2\%. The study results show that the user's ease and attitude have the highest value and interest in behavior. Therefore the East Java provincial government can maintain the procurement application.
\end{abstract}

\section{KEYWORDS:}

Convenience of Use, Influences of Admission, Goods/Services Procurement Application, Technology Acceptance Model, Users Satisfaction Level

\section{1 | INTRODUCTION}

The procurement of Government goods and services has an important role in the implementation of national development to improve public services and develop national and regional economies. To realize the reliable government's procurement of goods and services, and information technology-based instrument is needed. The government's procurement should provide value 
for money and contribute to the increased use of domestic products, enhance the role of micro-enterprises, small businesses, and medium-sized businesses as well as sustainable development and also carry out tasks and functions efficient, effective, transparent, open, competitive, fair and accountable procurement

For this reason, the East Java Provincial Government took a necessary step following the duties, functions, and authorities to accelerate the procurement of Government goods/services. It implemented all government procurement of goods/services through an Electronic Procurement System. The system should abide by the Presidential Instruction Number 1 the year 2015 concerning the acceleration of the procurement of goods/services. It also implemented the support systems, including the Procurement of Goods/Services, to increase national economic growth.

The authors aim to measure and test the practicality of the Procurement of Goods/Services, measuring how much influence the acceptance and ease of use of Procurement of Goods/Services, and measuring the level of user satisfaction with the TAM method (Technology Acceptance Model). TAM (Technology Acceptance Model) is one of the research models used to predict the adoption of information technology 11 . Through the TAM (Technology Acceptance Model) method, the assumption is that when users use a new information system, two factors influence it, namely the perception of Ease of Use Perceived and Usefulness Perceived benefits 2 .

The TAM Model (Technology Acceptance Model) conceptualizes how users receive and use new technology. Originally from a psychological theory approach to explain users who refer to the beliefs, attitudes, interests, and relationships of user behavior. TAM (Technology Acceptance Model) has three different construct models, namely: TAM 1 contains five (5) constructs, while TAM 2 includes eleven (11) constructs, and TAM 3 contains seventeen (17) constructs. The author uses the TAM 1 method (Technology Acceptance Model) because the variables used are considered sufficient to answer the formulation of the problem that will be used in measuring the Procurement of Goods/Services (STEEL APPLICATIONS) in the Regional Devices Organization in the East Java Province.

The author also uses the TAM-1 method because it has sufficient support in solving problems whose context is not too complicated. Thus, the method is widely used for modeling the adoption and use of information technology. It has been proven to be very predictive in the adoption and use of Information Technology.

TAM (Technology Acceptance Model) is considered the best in explaining user behavior towards new information technology systems. Existing research also shows that the truth of TAM (Technology Acceptance Model) for various types of systems for the use of information technology in various institutions and companies has been recognized by researchers in the world ${ }^{3]}$.

Theoretically and practically, the TAM method is the model that is considered most appropriate in explaining how users accept a system. This measurement goal is used to help model and predict user acceptance so that it can be designed an improvement step to increase the level of acceptance of goods and services procurement services in carrying out procurement of goods and services that are transparent and accountable and timely.

\section{2 | MATERIAL AND METHOD}

\section{1 | Material}

In this study, the method used for the correlation test is Spearman (Spearman Rank Correlation Coefficient) [4]6]. This method is used to test the hypothesis of the relationship between two variables. This statistic is sometimes called rho is written with $r_{s}$ which is a measure of association (relationship or relationship) where both variables are measured at least on an ordinal scale so that the objects or individuals studied can be ranked in two sequential sequences [1] 2] 7, 8 .

Association measurement uses numerical values to determine the level of association or the strength of the relationship between variables. Two variables are said to associate if one variable's behavior affects the other variables. If there is no influence, the two variables are called independent. The Spearman correlation value is between $-1<r_{s}<1$. If the value of $r_{s}=0$, it means there is no correlation between independent and dependent variables. The value of $r_{s}=+1$ means that there is a positive relationship between the independent and dependent variables. Value $=-1$ means there is a negative relationship between independent and dependent variables. 
TABLE 1 Likert with four points.

\begin{tabular}{lc}
\hline Positive Statement & Value \\
\hline Strongly agree (SS) & 4 \\
Agree (S) & 3 \\
Disagree (TS) & 2 \\
Strongly disagree (STS) & 1 \\
\hline
\end{tabular}

This applies if the "+" and "-" signs indicate the direction of the relationship between the variables being operated. For the Spearman correlation test statistical formula are as follows.

$$
r_{s}=1-\left(6 \Sigma_{i=1}^{N} d_{i}^{2} /\left(N^{3}-N\right)\right.
$$

where: $r_{s}$ is a measure of association, $\mathrm{N}$ is the data, and $\mathrm{d}$ is the difference between two rank. In this study, the data collection was carried out by distributing the questionnaires to the respondents physically. The questionnaires were distributed to individuals who are responsible as commitment-makers in each regional device organization (OPD) within the East Java province. The questionnaires also distributed to UKPBJ employees and Election Working Groups that use Goods/Services Procurement Applications (APELBAJA).

The questionnaire is a list of statements compiled based on the variables in this research method; the form of the statement in this questionnaire is a closed questionnaire. The questionnaire is sent or delivered to each respondent. Variable measurements were carried out using a four (4) Likert scale point ${ }^{9}$, which can be explained in Table 1

\section{2 | Data Collection Methods and Research Instruments}

Rensis Likert developed the Likert scale in $1932^{2}$. The item-based scale is used to measure positive attitudes towards an object. It is done by asking several questions or statements where the statement is in the form of a questionnaire that can be calculated through a scale of answers with weights and categories, as shown in Table 1 above. Given a number of these statements, a conclusion is drawn. In this procedure, it is formed in the following way: (1) determining variables in the TAM 1 method (Technology Acceptance Model) that will be examined; and (2) arrange statements according to the indicators of each variable. Scoring. For Strongly Agree (SS) answers given a value of 4, and so on decreases until the Very Disagree (STS) answer is given a value of 1 .

\section{3 | Research variable}

The variable of this study consisted of dependent and independent variables. The variables in the TAM1 method (Technology Acceptance Model) have several indicators that are used to examine the acceptance of the use of the Procurement of Goods/Services. Variable groupings are as follows.

There is only one independent variable, i.e. perceived ease of use (X1). There are four dependent variables, i.e. perceived usefulness (Y1), attitude toward behavior (Y2), behavioral intention (Y3), and behavior (Y4).

\section{4 | Operational Definition of Variables}

This variable definition consists of dependent and independent variables. The independent variable includes perceived ease of use (X1). Perception of ease of use is defined as the level of ease of users in using the procurement system for goods/services. The indicators are easy to learn (X1.1), easy to use (X1.2), easy to understand (X1.3), and easy to get information (X1.4).

The dependent variables include perceived usefulness (Y1), attitude toward behavior (Y2), behavioral intention (Y3), and behavior (Y4). The usage benefits are defined as the level at which users believe that the use of a goods/services Procurement System would improve their performance. The indicators are speed (Y1.1), effectiveness (Y1.2), and information needs (Y1.3). The attitude toward behavior is defined as affections (feelings) of the user to accept or reject when using a goods/services procurement application. It is measured by a procedure that places the user on an evaluative scale of two poles such as good or bad, agree or reject, etc. The indicators are attitude of accepting (Y2.1), feeling happy (Y2.2), and feeling enjoy it (Y2.3). The behavioral 


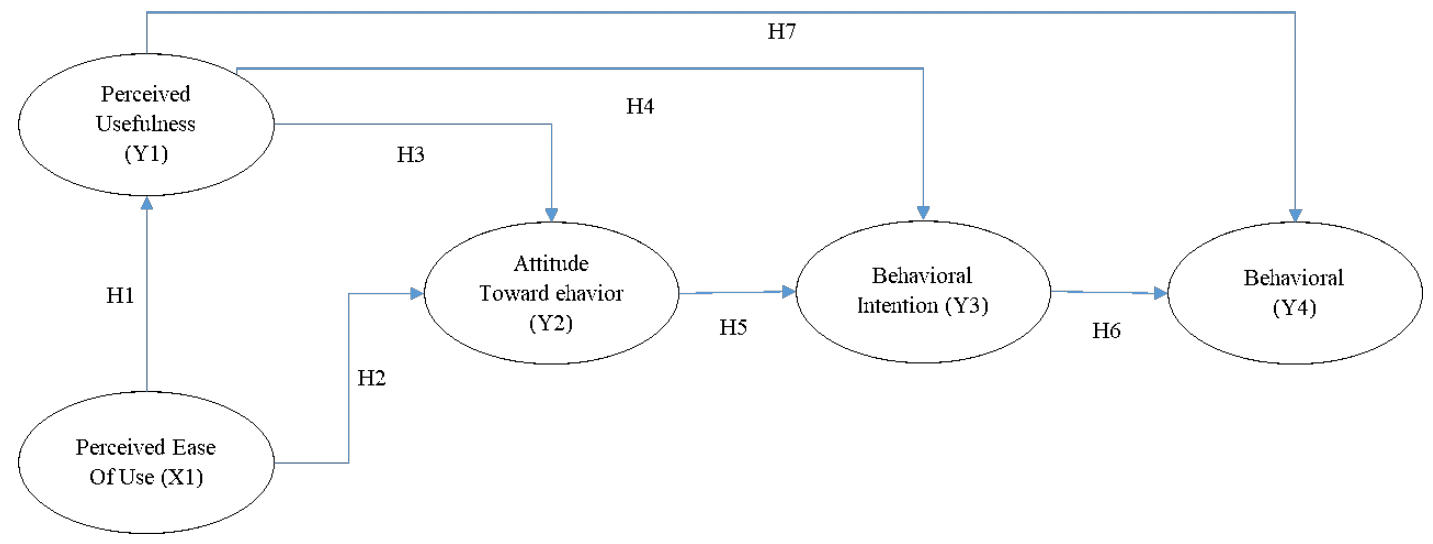

FIGURE 1 The conceptual model.

intention is defined as the degree to which the tendency of users to formulate a plan to continue to use or not use the Goods/Services Procurement Application. The indicators are opportunity to use (Y3.1), motivation because of other users (Y3.2), and motivation continues to use (Y3.3). The behavior is defined as a measurement of actual use, which is measured as the amount of frequency in the use of goods/services procurement applications. Anyone would be satisfied using the Procurement of Goods/Services if the system is easy to use and will increase productivity, which is reflected in the real conditions of use. The indicators are real use (Y4.1), frequency of use (Y4.2), and user satisfaction (Y4.3).

In the operational definition of the TAM-1 variable (Technology Acceptance Model), the author adjusts the indicators of dependent and independent variables based on case studies taken by researchers. The objectives are to enable the application of dependent and independent variable indicators onto the Goods/Services Procurement Application.

\section{5 | Hypothesis}

The research hypothesis models with the object of Goods/Services Procurement Application, taken from the relationship between the dependent and independent variables described as follows:

H1 Perceptions of ease of use have a significant effect on the benefits of using a Goods/Services Procurement Application.

H2 Perception of ease of use has a significant effect on behavior in using the Goods/Services Procurement Application.

H3 The benefits of using have a significant effect on attitudes of use or attitudes toward behavior in using the Procurement of Goods/Services.

H4 The benefits of using have a significant effect on behavioral interest in using Goods/Services Procurement Applications.

H5 The attitude of use or attitude towards behavior has a significant effect on interest in behavior in using the Procurement of Goods/Services.

H6 Interest in behavior has a significant effect on behavior in using Goods/Services Procurement Applications.

H7 The benefits of using have a significant effect on behavior in using Goods/Services Procurement Applications.

The hypothesis model in TAM1 (Technology Acceptance Model) is adjusted to the statements in TAM1 (Technology Acceptance Model) and adapted to the case studies on the Procurement of Goods/Services. The hypothesis model can be described in Figure 1.

\subsection{Correlation and Regression Analysis}

In this study included in the independent variable is the perception of ease of use, and the dependent variable is the benefits of use, attitudes toward behavior, interest in behavior, and behavior. Correlation analysis states the degree of relationship between two variables (bound and free) without regard to which variables change. 
TABLE 2 Respondents demography.

\begin{tabular}{lcr}
\hline Position & Num of Samples & Percentage \\
\hline Commitment Making Officer & 75 & $78.9 \%$ \\
Election Pokja Group & 20 & $21.1 \%$ \\
Total & $\mathbf{9 5}$ & $\mathbf{1 0 0 . 0} \%$ \\
\hline
\end{tabular}

\section{7 | Validity Test}

Validity and reliability testing is done to show the extent to which a measuring device measures what is measured and shows the extent to which a measuring device can be trusted or reliable. If the data is valid and reliable, then the research can continue [10]. Provisions for instrument validity if $r$ count is greater with $r$ table. The basic taking decision, $r$ count $>r$-table, then the variable is said to be valid. $r$ count $<r$ table, then the variable is invalid. Cronbach's alpha is used to measure the reliability of the indicators used in the research questionnaire. The data is said to be reliable if the Cronbach's Alpha value is above 0.5 [11].

\section{8 | Descriptive Analysis of Research Variables}

The descriptive analysis provides an overview of respondents' responses to research variables, namely perceived ease of use, perceived usefulness, attitude toward behavior, behavioral intention, and behavior. In this study, there are two (2) parameters, including the number of respondents (Commitment Making Officers) each OPD and respondent responses (Election Working Group) about the research variables. Of the two parameters will be processed into several data calculations consisting of the mean (average), minimum, and maximum. This descriptive analysis process was carried out on each variable using the SPSS 23 application [12].

\section{9 | Descriptive Analysis of Research Variables}

TAM 1 consists of five (5) dimensions, namely: perceived ease of use(X1), perceived usefulness(Y1), attitude toward behavior(Y2), behavioral intention(Y3), and behavior(Y4). In this descriptive analysis has the highest value obtained from the 4-point Likert scale, namely number four (4) as a statement strongly agree (SS), and has the lowest value of one (1) as a statement strongly disagree (STS), so if calculated to be $4-1=3: 4=0.75$. As a guideline to provide interpretation in conducting this descriptive analysis, the researcher uses the unit of numbers as follows: Very Bad/Very Low (1.00 - 1.75), Bad/Low (1.75 2.50), Good/High (2.50 - 3.25), and Very Good/Very High (3,25 - 4.00)

\section{3 | RESULTS AND DISCUSSION}

This part will be shown as a result of the research. In this study, the population is a commitment-making official who served in each office in the East Java provincial government. Researchers get a population in 2019 as many as 1900. The number of the population each year can change according to changes in the structure of each department. Respondents came from users of the Goods/Services Procurement Service consisting of Commitment Officials. They are working in 14 Agencies, 5 Hospitals, 9 Bureaus, 24 Offices, and 7 Offices in the East Java Provincial Government. The respondents served as Commitment Making Officers and Election Working Groups who served in the Division of Goods/Services Administration of the Regional Secretariat of the East Java Province Construction Secretariat. The researcher used the Slovin's formula to determine the research sample [13]. The Slovin's formula is formed as follows.

$$
n=\left(N / N\left(e^{2}+1\right)\right.
$$

Where $n$ is the sample size of population size (obtained from the total results of the total number of Commitment Making Officials and Election Working Groups). The $e$ is the percent sampling error tolerated. The $N$ is the population size (obtained from the total results of the total number of Commitment Making Officials and the total Number of Election Working Groups). The samples demography is shown in Table 2. 


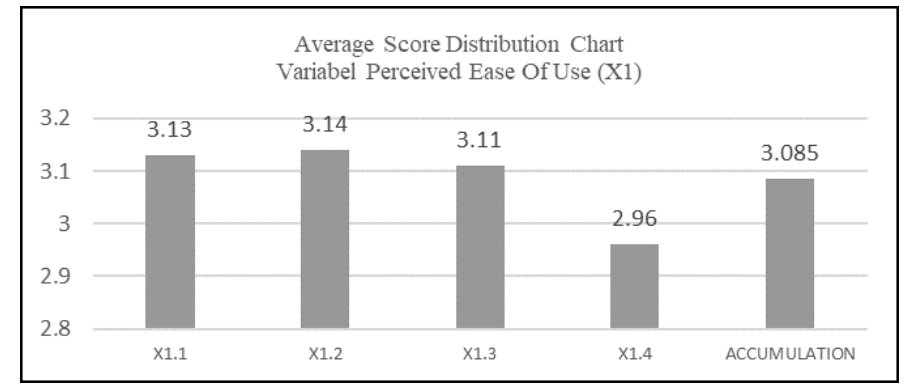

FIGURE 2 Graph of distribution of variable mean scores Perception of Ease of Use (X1).

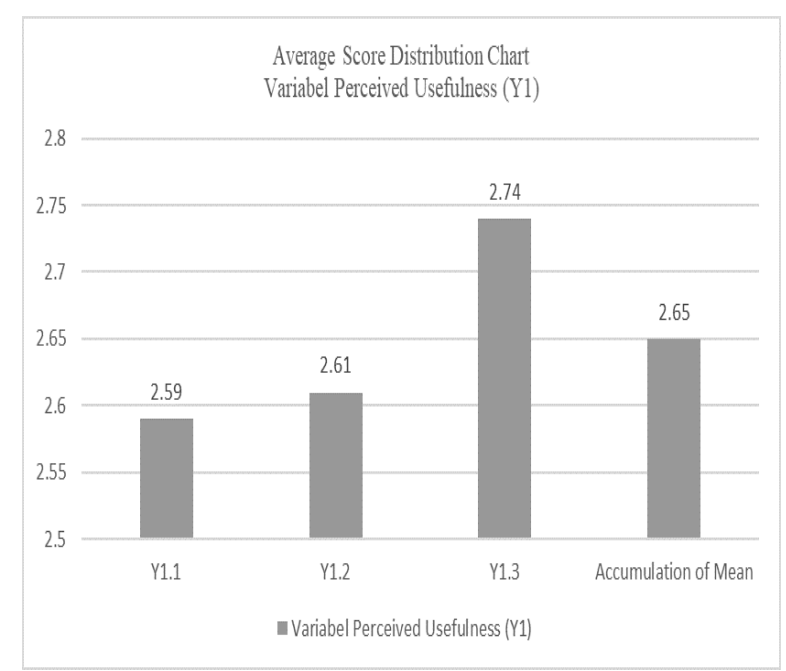

FIGURE 3 Graph of the mean score distribution distribution Benefits of Use (Y1).

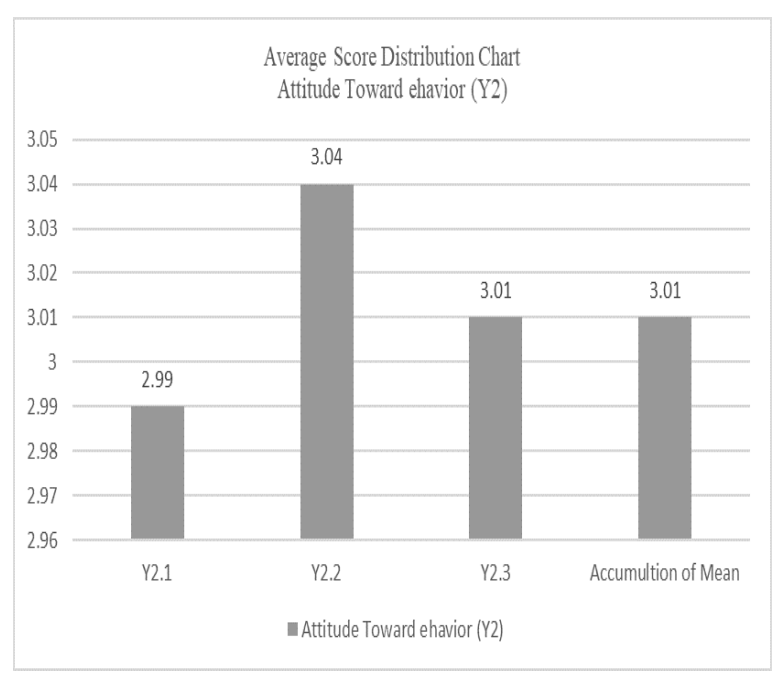

FIGURE 4 The graph of the distribution of the average score of the attitude variable towards behavior (Y2).

\section{1 | Perceived Ease of Use (X1)}

The perceived ease of use variable in this study has four (4) indicators, namely: Easy to learn (X1.1), Easy to use (X1.2), Easy to understand (X1.3) and Easy to get information (X1 .4). Recapitulation of respondents' answers to perceived ease of use in Figure 2 .

\section{2 | Perceived Usefulness (Y1)}

Variable perceived usefulness(Y1) in this study has three (3) indicators, namely: Speed (Y1.1), Effectiveness (Y1.2), and Information Needs (Y1.3). Recapitulation of respondents' answers to indicator variables perceived usefulness is shown in Figure 3.

\section{3 | Attitude Toward Behavior (Y2)}

Variable attitude toward behavior(Y2) in this study had three (3) indicators, namely: Attitude of accepting (Y2.1), Feelings of pleasure (Y2.2), and Feelings of enjoying (Y2.3). Recapitulation of respondents' answers to attitude indicator variables on attitude toward a behavior is shown in Figure 4. 


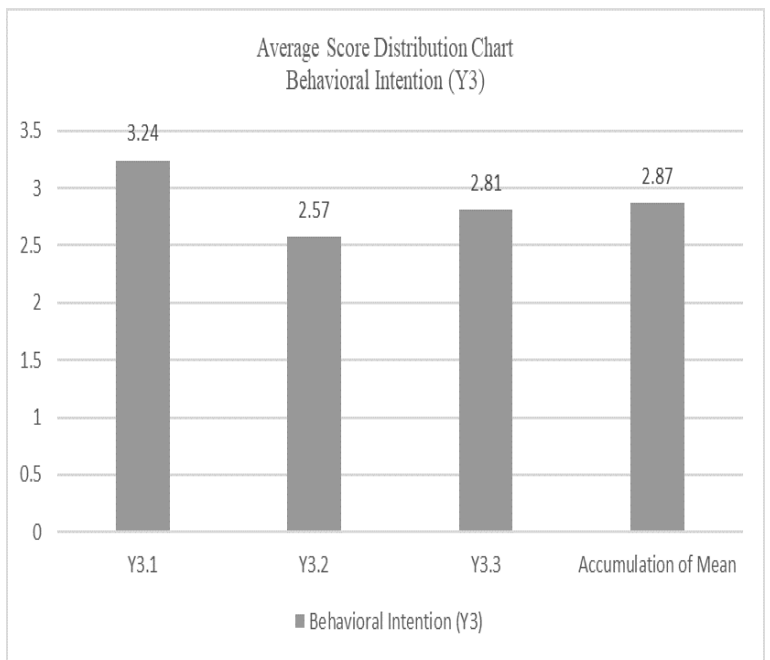

FIGURE 5 Graph of distribution of average score of interest in behavioral variables (Y3).

TABLE 3 Criteria for relationship level or correlation coefficient between variables.

\begin{tabular}{cl}
\hline Range Values & Information \\
\hline $0.00-0.20$ & There is almost no correlation \\
$0.21-0.40$ & Low correlation \\
$0.41-0.60$ & Medium correlation \\
$0.61-0.80$ & High correlation \\
$0.81-1.00$ & Perfect correlation \\
\hline
\end{tabular}

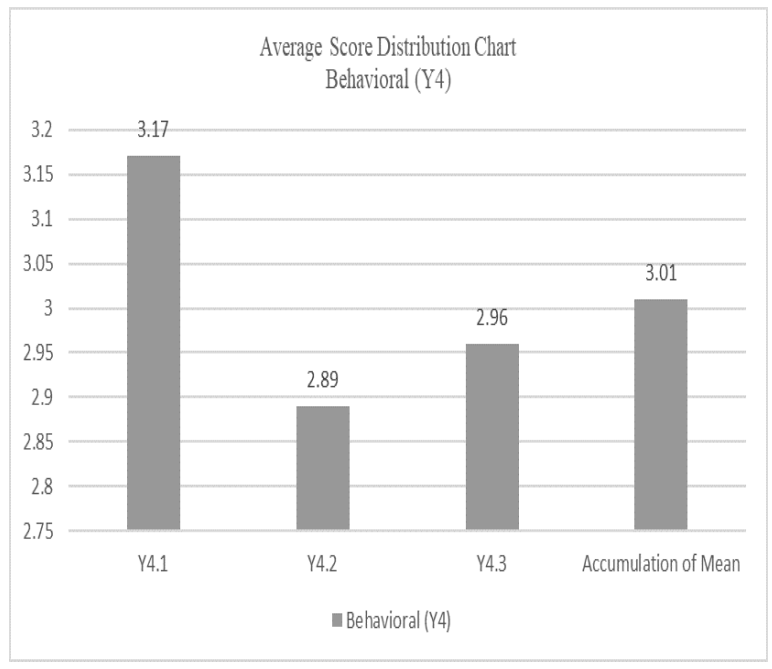

FIGURE 6 Graph of distribution of average score of behavioral variables (Y4).

TABLE 4 Inter variable correlation test results.

\begin{tabular}{lll}
\hline Correlation & Correlation Value & Correlation Category \\
\hline X with Y1 & $0,218^{*}$ & Significant \\
X with Y2 & $0,561^{* *}$ & Very Significant \\
Y1 with Y2 & $0,392^{* *}$ & Very Significant \\
Y1 with Y3 & $0,283^{* *}$ & Very Significant \\
Y1 with Y4 & 0,193 & Not Significant \\
Y2 with Y3 & $0,390^{* *}$ & Very Significant \\
Y3 with Y4 & $0,361^{* *}$ & Very Significant \\
\hline
\end{tabular}

\section{4 | Behavioral Intention (Y3)}

Variable behavioral intention (Y3) in this study has three (3) indicators, namely: Opportunity to use (Y3.1), Motivation because of other users (Y3.2), and Motivation while using (Y3.3). The recapitulation of respondents' answers to the behavioral intention indicator variables is shown in Figure 5.

\section{5 | Behavior(Y4)}

The variable behavior (Y4) in this study has three (3) indicators, namely: Real use (Y4.1), Frequency of use (Y4.2), and User satisfaction (Y4.3). The recapitulation of respondents' answers to the variable behavior indicator (Y4) is shown in Figure 6.

\section{6 | Correlation Analysis}

Correlation analysis illustrates the relationship between independent variables $(\mathrm{X})$ and non-independent variables $(\mathrm{Y})$ can be tested in the form of models used and the closeness of the relationship (correlation) to express the accuracy and accuracy of the regression line equations obtained. The following are the results of the correlation analysis tested using SPSS 23 in accordance with the TAM 1 path diagram (Technology Acceptance Model) in the Goods/Services Procurement Service Application and using the reference to the Spearman method (Spearman Rank Correlation Coefficient), for 95 correspondents and the significance level that has been set is 0.05 . Criteria for the level of relationships or correlation coefficients between variables ranging from \pm 0.00 to $\pm 1.00(+)$ are positive and (-) is negative. The interpretation criteria are shown in Table $3^{[14]}$.

This study uses the Spearman Formula (Eq. 1) to test the correlation between two variables. The measurement uses a twotailed test. The result which uses spearman formula is shown in Table 4. The first column is the Inter-Variable Correlation (path diagram). The second column is the value of each correlation. The last column is the category of each correlation. 
TABLE 6 Model summary.

TABLE 5 Significance level.

\begin{tabular}{ll}
\hline Level & Description \\
\hline if sig $(p)<0,01$ & Very significant (strong significant) \\
if sig $(p)<0,05$ & Significant \\
if sig $(p)>0,05$ & Not significant \\
\hline
\end{tabular}

\begin{tabular}{rrrrr}
\hline Correlation & $\mathbf{R}$ & $\boldsymbol{R}^{2}$ & Adjusted $\boldsymbol{R}^{2}$ & $S_{e}$ \\
\hline X1 with Y1 & $0.367 \mathrm{a}$ & 0.135 & 0.125 & 170.813 \\
X1 with Y2 & $0.622 \mathrm{a}$ & 0.387 & 0.380 & 1.53204 \\
Y1 with Y2 & $0.489 \mathrm{a}$ & 0.239 & 0.231 & 1.70657 \\
Y1 with Y3 & $0.340 \mathrm{a}$ & 0.115 & 0.106 & 1.76179 \\
Y2 with Y3 & $0.471 \mathrm{a}$ & 0.222 & 0.214 & 1.65246 \\
Y1 with Y4 & $0.317 \mathrm{a}$ & 0.101 & 0.091 & 1.54222 \\
Y3 with Y4 & $0.363 \mathrm{a}$ & 0.132 & 0.122 & 1.51552 \\
\hline
\end{tabular}

TABLE 7 Coefficients X1 with Y1.

\begin{tabular}{|c|c|c|c|c|c|}
\hline Model & $\begin{array}{l}\text { Unstan } \\
\text { B }\end{array}$ & $\begin{array}{l}\text { dardized Coeff. } \\
\text { SE }\end{array}$ & $\beta$ & t & Sig \\
\hline & $\begin{array}{l}4.439 \\
0.284\end{array}$ & $\begin{array}{l}0.936 \\
0.075\end{array}$ & 0.367 & & $\begin{array}{l}0.000 \\
0.000\end{array}$ \\
\hline
\end{tabular}

The value marked with one star $\left(^{*}\right)$ means that it has a significant correlation to the number of significance (2-tailed) of 0.05 at the level or level of $5 \%$. The value marked with two-star sign $(* *)$ means that it has a very significant correlation to the number of significance (2-tailed) of 0.01 at the level or level of $1 \%$. If the correlation is significant at $1 \%$, it is also significant at $5 \%$, if it is significant at $5 \%$, it is not necessarily significant at the level of $1 \%$. If . If there is no one asterisk $(*)$ and two $(* *)$, then the correlation between correlations is very weak, then the way to read it is also the same, that is, by following the significance level previously set at 0.05 . The relationship in the table above is significant because the significance number is smaller than $0.05^{(15)}$. A significant correlation or chance of alpha error is given the symbol p (probability of Alpha Error). The probability of error (written "sig" at the SPSS program output) can be seen at the significance level as shown in Table 5.

\section{7 | Regression Analysis}

Regression analysis is used to predict or test the effect of an independent variable or independent variable on the dependent variable or dependent variable. The following are the results of the regression analysis tested using SPSS 23 in accordance with the TAM 1 path diagram (Technology Acceptance Model) in the Goods/Services Procurement Service Application).

\section{8 $\mid$ Regression X1 with Y1}

Table 6 explains the magnitude of the correlation value or relationship (R) that is equal to 0.367 and explains the percentage of the influence of independent variables on the dependent variable. It is called the coefficient of determination, which is the result of R square. The output above obtained the coefficient of determination (R2) of 0.135 , which implies that the influence of the independent variable on perceived ease of use (X1) on the dependent variable of use benefits (Y1) is 13.5

On Table 7, Perception of Ease of Use (X1) has a positive and significant effect on the Benefits of Use in using APELBAJA (Goods/Services Procurement Application) (Y1) with a value of 3,806 and a significance value of 0,000 which is below 0.05 which means the hypothesis is accepted.

It can be explained that respondents are very concerned about the factors of ease of use, easy to understand, easy to learn, and easy to get information such as information on how to use APELBAJA (Goods/Services Procurement Service Application). In the use of APELBAJA (Goods/Services Procurement Service Application), respondents felt it was easy to use so that respondents felt a benefit from the convenience that was seen in terms of speed and effectiveness of the time respondents used. Respondents felt comfortable learning to use technology if the technology was secure. The ease of using APELBAJA (Goods/Services Procurement Service Application) makes it easy for respondents to get the information needed or sought, such as information on how to use APELBAJA (Goods/Services Procurement Service Application).

\section{9 | Regression X1, Y1 to Y2}

Table 6 also explains the magnitude of the correlation value or relationship (R), which is equal to 0.622 and explains the percentage of the influence of independent variables on the dependent variable. It called the coefficient of determination, which 
TABLE 8 Coefficients X1 with Y2.

\begin{tabular}{llllll}
\hline Model & \multicolumn{2}{l}{ Unstandardized Coeff. } & \multirow{\beta}{*}{$\boldsymbol{\beta}$} & $\mathbf{t}$ & Sig \\
\hline B & SE & & & \\
TX & 2.732 & 0.839 & & 3.256 & 0.002 \\
& 0.512 & 0.067 & 0.622 & 7.655 & 0.000 \\
\hline
\end{tabular}

TABLE 10 Coefficients Y1 with Y3.

\begin{tabular}{|c|c|c|c|c|c|}
\hline Model & Unsta & lardized Coeff. & $\beta$ & $\mathbf{t}$ & Sig \\
\hline (Constant) & 5.870 & 0.810 & & 7246 & 0000 \\
\hline TX & 0.347 & 0.099 & 0.340 & 3.485 & 0.001 \\
\hline
\end{tabular}

TABLE 9 Coefficients Y1 with Y2.

\begin{tabular}{llllll}
\hline Model & \multicolumn{2}{l}{ Unstandardized Coeff. } & $\beta$ & t & Sig \\
\hline B & SE & & & \\
\hline TX & 2.732 & 0.839 & & 3.256 & 0.002 \\
& 0.512 & 0.067 & 0.622 & 7.655 & 0.000 \\
\hline
\end{tabular}

TABLE 11 Coefficients Y2 with Y3.

\begin{tabular}{|c|c|c|c|c|c|}
\hline Model & $\begin{array}{l}\text { Unstan } \\
\text { B }\end{array}$ & $\begin{array}{l}\text { dardized Coeff. } \\
\text { SE }\end{array}$ & $\beta$ & $\mathbf{t}$ & Sig \\
\hline (Constant) & 4.542 & 0.810 & & 5.607 & 0.000 \\
\hline TX & 0.451 & 0.088 & 0.471 & 5.149 & 0.000 \\
\hline
\end{tabular}

is the result of $\mathrm{R}$ square. The output above obtained the coefficient of determination (R2) of 0.387, which implies that the influence of independent variables on the perception of ease of use (X1) on the dependent variable attitudes toward behavior (Y2) is $38.7 \%$ while other variables influence the rest.

Table 8 shows that Perception of ease of use (X1) has a positive and significant effect on attitudes toward behavior in using APELBAJA (Goods/Services Procurement Service Application) (Y2) with a value of 7.655 and a significance value of 0,000 which is below 0.05 which means the hypothesis is accepted.

It can be explained that respondents will pay attention to aspects of ease of use when respondents use APELBAJA (Goods/Services Procurement Service Application). By the daily reality, every time using APELBAJA (Goods/Services Procurement Service Application) as a service system for procurement of goods/services within the East Java Provincial Government, respondents always feel happy, enjoy and show acceptance. Also, because APELBAJA (Goods/Services Procurement Service Application) is a service system for the procurement of new goods/services, respondents will not find it difficult to use. The ease in using APELBAJA (Goods/Services Procurement Service Application) allows the respondent to do a non-physical visit to the Goods/Service's procurement Unit for submitting packages that are tendered. They can avoid a long queue or wait like a manual service process so that respondents feel happy when using them.

Table 6 also explains the magnitude of the correlation value or the relationship (R), which is equal to 0.489 and explains the percentage effect of independent variables on the dependent variable. It is called the coefficient of determination, which is the result of R Square. The Output above obtained the coefficient of determination (R2) of 0.239, which implies that the influence of the use benefit free variable (Y1) on the dependent variable attitude towards behavior (Y2) is $23.9 \%$ while other variables influence the rest.

On Table 9 is shown that Benefits of Use (Y1) have a positive and significant effect on attitudes towards behavior in using APELBAJA (Goods/Services Procurement Application) (Y2) with a value of 5.402 and a significance value of 0,000 which is below 0.05 , which means the hypothesis is accepted.

The results of this study indicate that the Use Benefits (Y1) has a positive and significant effect on attitudes towards behavior (Attitude Toward Using) (Y2). Based on this study, in reality, the respondents gave a positive appreciation related to the use of APELBAJA (Goods/Services Procurement Service Application) specifically on aspects such as the existence of corrective feedback or a review between UKPBJ and KDP. This is certainly very supportive of the attitude of respondents to the use of APELBAJA (Goods/Services Procurement Service Application). Respondents felt happy, enjoyed, and accepted the APELBAJA (Goods/Services Procurement Service Application) within the East Java Provincial Government.

\subsection{0 | Regression Y1, Y2 to Y3}

Table 6 also explains the magnitude of the correlation value or relationship (R) that is equal to 0.340 and explains the percentage of the influence of independent variables on the dependent variable. It is called the coefficient of determination, which is the result of R square. The Output above obtained the coefficient of determination (R2) of 0.115 , which implies that the influence of the benefit variable free use (Y1) on the behavioral interest dependent variable (Y3) is 11.5\% while other variables influence the rest. 
TABLE 12 Coefficients Y1 with Y4.

\begin{tabular}{|c|c|c|c|c|c|}
\hline Model & $\begin{array}{l}\text { Unsta } \\
\text { B }\end{array}$ & $\begin{array}{l}\text { dardized Coeff. } \\
\text { SE }\end{array}$ & $\beta$ & $\mathbf{t}$ & Sig \\
\hline (Constant) & 6.791 & 0.709 & & 9.477 & 0.000 \\
\hline TX & 0.281 & 0.087 & 0.317 & 3.227 & 0.002 \\
\hline
\end{tabular}

TABLE 13 Coefficients Y3 with Y4.

\begin{tabular}{|c|c|c|c|c|c|}
\hline Model & $\begin{array}{l}\text { Unsta } \\
\text { B }\end{array}$ & $\begin{array}{l}\text { dardized Coeff. } \\
\text { SE }\end{array}$ & $\beta$ & $\mathbf{t}$ & Sig \\
\hline (Constant) & 6.307 & 0.740 & & 8.525 & 0.000 \\
\hline $\mathrm{TX}$ & 0.315 & 0.084 & 0.363 & 3.753 & 0.000 \\
\hline
\end{tabular}

Table 10 shows that Benefits of Use (Y1) have a positive and significant effect on the Interest of Behavior in using APELBAJA (Goods/Services Procurement Application) (Y3) with a value of 3.485 and a significance value of 0.001 which is below 0.05 , which means that the hypothesis is accepted.

When the respondent gives a positive appreciation for the use of APELBAJA (Goods/Services Procurement Service Application), this is one of the benchmarks for the user's interest in using technology. Respondents made aspects of the use of benefits for a tendency to use APELBAJA (Goods/Services Procurement Service Application). There are many benefits in using APELBAJA (Goods/Services Procurement Services), i.e., accelerating the respondent's activity, increasing time effectiveness, and meeting information needs. These benefits motivate the existing users or new visitors to continue using the technology. In this case, there will be a feeling of trust to continue using the technology. On the other hand, because APELBAJA (Goods/Services Procurement Service Application) is a service system for the procurement of goods/services that must be used by respondents as stipulated by the East Java Provincial Government. This is the Procurement of Goods/Services Section of the East Java Provincial Administration as The Goods/Services Procurement Unit (UKPBJ), which makes respondents tend to keep using it.

Table 6 also explains the magnitude of the correlation value or relationship (R), which is equal to 0.471 and explains the percentage of the influence of independent variables on the dependent variable. It is called the coefficient of determination, which is the result of R square. The Output above obtained the coefficient of determination (R2) of 0.222, which implies that the influence of the independent variable attitudes toward behavior (Y2) on the behavioral interest dependent variable (Y3) is $22.2 \%$ while other variables influence the rest.

On Table 11, attitudes towards behavior (Y2) have a positive and significant effect on the Interest in behavior in using application (Goods/Services Procurement Service Application) (Y3) with a value of 5,149 and a significance value of 0,000 which is below 0.05 which means the hypothesis is accepted.

The results above explain that attitudes toward behavior (Y2) have a positive and significant effect on behavioral intention to use (Y3). In this study, respondents have an attitude of accepting the use of the application (Goods/Services Procurement Application). They feel happy and enjoy and always use the application (Goods/Services Procurement Services) with the intensity of frequent use in a day. Respondents motivated other users to continue using APELBAJA (Goods/Services Procurement Service Application).

\subsection{1 | Regression Y1, Y3 to Y4}

Table 6 also explains the magnitude of the correlation value or relationship (R), which is equal to 0.317 and explains the percentage of the influence of independent variables on the dependent variable. It is called the coefficient of determination, which is the result of $\mathrm{R}$ square. The output obtained the coefficient of determination (R2) of 0.101, which implies that the influence of the benefit variable free use (Y1) on the behavior variable (Y4) is $10.1 \%$. In contrast, the rest is influenced by other variables.

On Table 12, Interest in Behavior has a positive and significant effect on user behavior in using APELBAJA (Goods / Services Procurement Service Application) (Y4) with a value of 3.753 and a significance value of 0,000 which is below 0.05, which means the hypothesis is accepted. The results of the analysis in this study explained that the Interest in Behavior (Y3) has a positive influence on user behavior in using APELBAJA (Goods/Services Procurement Service Application) (Y4). Users tend to continue to use APELBAJA (Goods/Services Procurement Service Application).

Table 6 also explains the magnitude of the correlation value or relationship (R), which is equal to 0.363 and explains the percentage of the influence of independent variables on the dependent variable. It is called the coefficient of determination, which is the result of $\mathrm{R}$ square. The output above obtained the coefficient of determination (R2) of 0.132, which implies that the influence of interest-free behavior variable (Y3) on behavior dependent variable (Y4) is 13.2\% while other variables influence 
TABLE 14 Hypothesis summary.

\begin{tabular}{|c|c|c|c|c|}
\hline Hypothesis & Description & Value & Sig & Decission \\
\hline H1 & $\begin{array}{l}\text { Perception of Ease of Use (X1) has a positive and significant effect on the } \\
\text { Benefits of Using a Goods/Services Procurement Service Application (Y1). }\end{array}$ & 3,806 & 0,000 & Be accepted \\
\hline $\mathrm{H} 2$ & $\begin{array}{l}\text { Perception of ease of use (X1) has a positive and significant effect on attitudes } \\
\text { toward behavior in using the Goods/Services Procurement Service Application } \\
\text { (Y2). }\end{array}$ & 7,655 & 0,000 & Be accepted \\
\hline H3 & $\begin{array}{l}\text { Benefits of Use (Y1) have a positive and significant effect on attitudes toward } \\
\text { behavior in using the Goods/Services Procurement Service Application (Y2). }\end{array}$ & 5,402 & 0,000 & Be accepted \\
\hline $\mathrm{H} 4$ & $\begin{array}{l}\text { Benefits of Use (Y1) have a positive and significant effect on User behavior's } \\
\text { interest in Using Goods/Services Procurement Services (Y3). }\end{array}$ & 3,485 & 0,001 & Be accepted \\
\hline H5 & $\begin{array}{l}\text { Attitudes toward behavior (Y2) have a positive and significant effect on the } \\
\text { interest in user behavior in using the goods/services procurement service (Y3). }\end{array}$ & 5,149 & 0,000 & Be accepted \\
\hline H6 & $\begin{array}{l}\text { Interest in User Behavior in Using Goods/Services Procurement Services) (Y3) } \\
\text { has a positive and significant effect on Behavior in using Goods/Services } \\
\text { Procurement Services (Y4). }\end{array}$ & 3,753 & 0,000 & Be accepted \\
\hline H7 & $\begin{array}{l}\text { Use Benefits (Y1) have a positive and significant effect on Behavior in using } \\
\text { the Goods/Services Procurement Service Application (Y4). }\end{array}$ & 3,277 & 0,002 & Be accepted \\
\hline
\end{tabular}

TABLE 15 Hypothesis summary.

\begin{tabular}{lccc}
\hline Variable & Original sample & T-Statistics & P-Value \\
\hline Attitude Toward Behavior $\Rightarrow$ Behavioral Intention & 0.478 & 5.908 & 0 \\
Behavioral Intention $\Rightarrow$ Behavioral & 0.324 & 2.767 & 0.006 \\
Perceived Easy of Use $\Rightarrow$ Attitude Toward Behavior & 0.486 & 7.255 & 0 \\
Perceived Easy of Use $\Rightarrow$ Perceived Usefulness & 0.351 & 2.944 & 0.003 \\
Perceived Usefulness $\Rightarrow$ Attitude Toward Behavior & 0.365 & 5.235 & 0 \\
Perceived Usefulness $\Rightarrow$ Behavioral & 0.28 & 2.448 & 0.015 \\
Perceived Usefulness $\Rightarrow$ Behavioral Intention & 0.15 & 1.458 & 0.145 \\
\hline
\end{tabular}

the rest. On Table 13, Benefits of Use (Y1) have a positive and significant effect on Behavior (Y4) with a value of 3.277 and a significance value of 0.002 , which is below 0.05 , which means the hypothesis is accepted.

It can be explained from real usage. The respondents felt that APELBAJA (Goods/Services Procurement Service Application) accelerated their vehicles' parking and felt their time was more effective. Hence, they always used it to submit tender packages. The benefits of using in use that are obtained by respondents then lead to satisfaction in themselves. This satisfaction also prompted respondents to continue using APELBAJA (Goods/Services Procurement Service Application). The hypothesis summary is shown in Table 14.

Tabel 15 shows the testing result on the given hypothesis. The hypothesis is accepted when T-statistic $>1,97$. The different result is obtained while PLS runs this research. Perceived Usefulness (X1) has no significant influence on Behavioral Intention (Y3).

\section{4 | CONCLUSION}

Based on the results of the analysis of the acceptance of APELBAJA (Goods/Services Procurement Application) with the Technology Acceptance Model (TAM) method on Regional Devices in the East Java Provincial Government environment, the perceived ease of use (X1) relationship with an attitude towards behavior (attitude toward a behavior) (Y2), with regression test results of $38.7 \%$. The highest value is considered to be the most influential on the measurement of acceptance of APELBAJA (Goods/Services Procurement Service Application) in the East Java Provincial Government environment. Users also find it easy when using APELBAJA (Goods/Services Procurement Services Application). The users can learn APELBAJA (Goods/Services Procurement Services) quickly because it provides sufficient information about how to use it. It has been equipped with tutorial features in the Application. Thus, the Procurement of Goods/Services Section Development Administration Bureau East Java Province Regional Secretariat as the Procurement Unit for Goods/Services organized socialization events and provided technical assistance and consultation. In the end, the end-users feel happy and comfortable using the application.

The lowest value is on the perceived usefulness (Y1) relationship with behavior (Y4), which is $10.1 \%$. It can be concluded that users perceived that the application works slowly and ineffectively. In the production environment, the users did not use the 
application at all times. Several end-users do not have a package submitted to UKPBJ but still uses the manual system because the package is carried out under 200 million for Non-Consultancy and 100 million down for Consultants.

Further research should expand the object and place of study so that there will be more diverse data so that the results can be more complex and detailed. If further research wants to examine the TAM method (Technology Acceptance Model), you should add external variables in the TAM model or add other variables that are still appropriate, so that the results obtained will be more complete.

\section{References}

1. Davis FD. A Technology Acceptance Model For Empirically Testing New End-User Information Systems: Theory And Results. PhD thesis, Massachusetts Institute of Technology; 1985.

2. Davis FD. Perceived Usefulness, Perceived Ease of Use, and User Acceptance of Information Technology. MIS Quarterly: Management Information Systems 1989;13(3):319-339.

3. Vaidyanathan G, Sabbaghi A, Bargellini M. User Acceptance of Digital Library: an Empirical Exploration of Individual and System Components. Issues in Information Systems 2005;6(2):279-285.

4. Tobi H, Kampen JK. Research design: the methodology for interdisciplinary research framework. Quality and Quantity 2018 may;52(3):1209-1225.

5. Donald RC, Pamela SS. Business Research Methods. New Delhi: Tata Mac Graw Hills; 2003.

6. Guritno S, Rahardja U. Theory and Application of IT Research Metodelogi Penelitian Teknologi Informasi. Yogjakarta: Andi; 2011.

7. Jogiyanto H. Sistem Informasi Keperilakuan. 1 ed. Yogyakarta: Andi Offset; 2007.

8. Fred N Kerlinger HBL. Foundations of Behavior Research. 3 ed. Australia: Wadsworth Publishing; 1999.

9. Djaali H. Psikologi Pendidikan. Jakarta: PT. Bumi Aksara; 2008.

10. Nazir M. Metode Penelitian. 5 ed. Jakarta: Ghalia Indonesia; 2003.

11. Ghozali I. Aplikasi Multivariate dengan Proses SPSS. Bogor: Ghalia Indonesia; 2013.

12. Agung WE. Aplikasi Praktis SPSS dalam Penelitian. 2 ed. Yogyakarta: Gava Media; 2012.

13. Ryan TP. Sample Size Determination and Power. 1 ed. Hoboken, N.J: Wiley; 2013.

14. Prastito A. Statistik Menjadi Lebih Mudah Dengan SPSS 17. Jakarta: Elex Media Koputindo; 2000.

15. Nisfiannoor M. Pendekatan Statistika Modern untuk Ilmu Sosial. Jakarta: Salemba Humanika; 2009.

How to cite this article: Odi M., Erma S., (2020), Acceptance Analysis of The East Java Province E-Procurement System Using TAM Method, IPTEK The Journal of Technology and Science, 31(2):127-138. 